\title{
1. Adopting competition law in Asia: an increasingly complex reality
}

Steven Van Uytsel

\section{INTRODUCTION}

For a long time, the Philippines and Japan were the only Asian countries with a competition law. The oldest competition law in Asia, that of the Philippines, dates back to 1925 . $^{1}$ Japan enacted its competition law in $1947 .^{2}$ The influence of the United States (US) on these competition laws is undisputed. The United States, in the end, exerted political control over these countries. The Philippines was governed by the US through the Insular Government of the Philippine Islands. ${ }^{3}$ Japan was de facto controlled by the US through its leadership in the Supreme Command of the Allied Powers. ${ }^{4}$

This chapter will claim that the creation of the abovementioned competition laws occurred in a rather simple reality. The imposition of US competition law on the Philippines and Japan was possible due to the latter countries' position of dependence on the US. Even though there may have been other scholarly ideas on competition, for example in Europe, it was not possible for these ideas to break through to the lawmaking process. In addition, scholarship on competition in general, but on competition-related economics in particular, was less developed. In a scattered world, emerging from the destruction of a world war, there was also no international forum that could exert pressure or influence on what competition law should look like. Each of these elements has changed over the past seven decades, the period in which Asian countries have adopted a competition law. This chapter will elaborate on that evolution.

This chapter is structured as follows. Section 2 elaborates on the disappearance of the United States' monopoly position as merchant in competition law ideas. Several other countries, some more influential than others, have positioned their competition laws as

1 See, e.g., Alizedney M. Ditucalan, 'Institutional Design of Philippine Competition Law' (2018) 8 KLRI Journal of Law and Legislation 29; Rafaelita M. Aldaba and Geronimo S. Sy, 'Designing a Cooperation Framework for Philippine Competition and Regulatory Agencies' (2014) Discussion Paper Series No 2014-31, available at: https://pidswebs.pids.gov.ph/CDN/PUBLICATIONS/pidsdps1431.pdf (accessed 5 October 2019); Tristan A. Catindig, 'The ASEAN Competition Law Project: The Philippines Report' (2001), available at: www.jftc.go.jp/eacpf/02/philippines_r.pdf (accessed 5 October 2019); see also Alizedney M. Ditucalan, Chapter 13 of this volume.

${ }_{2}$ Act No 54 of 1974, shiteki dokusen no kinshi oyobi kousei torihiki no kakuho ni kan suru houritsu [Act Concerning the Prohibition of Private Monopolies and the Assurance of Fair Trade] (Antimonopoly Act).

3 See Leia Castañeda Anastacio, The Foundations of the Modern Philippine State: Imperial Rule and the American Constitutional Tradition in the Philippine Islands, 1898-1935 (Cambridge University Press 2016).

4 See Matthew R. Augustine, 'A Guide to Research on the Allied Occupation of Japan', available at: www.columbia.edu/ hds2/BIB95/02occupation_augustine.htm\#02 (accessed 5 October 2019). 
alternative models for designing a competition law. Still other countries have, without actively pursuing it, been regarded as offering an alternative model. If different competition law regimes exist, a clash is almost unavoidable. This is especially so if the result of the application of a competition law transgresses borders. Two responses have been developed. In Section 3, this chapter details one such response. Under the influence of the law and economics scholarship, there has been a call to achieve convergence on economic standards. Another response, which will be explained in Section 4, is to recognize that diverging views on competition law exist and to learn from the differences, in the hope that convergence can still be achieved. This view is mainly developed within the framework of the International Competition Network (ICN). Divergence has also been advocated for by scholarship on competition law and countries in economic transition or developing countries. This scholarship holds that, as will be explained in Section 5, not all countries can and should adopt the same competition law. Section 6 will particularize how the tension between convergence and divergence has been fortified in the Association of Southeast Asian Nations (ASEAN) framework. Section 7 concludes by summarizing the tensions complicating the conceptualization of a competition law.

\section{THE END OF THE UNITED STATES' MONOPOLY AS COMPETITION-RELATED IDEA MERCHANT ${ }^{5}$}

Competition law in Asia has long been linked to the United States. When the Philippines was under the control of the United States, its government enacted Act No. 3247, on 1 December 1925..$^{6}$ This Act, entitled An Act to Prohibit Monopolies and Combinations in Restraint of Trade, ${ }^{7}$ is said to be a copy of the United States' Sherman Act. ${ }^{8}$ The Act was largely replaced by the restraint of trade provision of the 1930 Revised Penal Code. ${ }^{9}$ Again, these provisions were a copy of the provisions of the Sherman Act: ${ }^{10}$

\footnotetext{
5 The concept of the idea merchant has been borrowed from Mel Marquis: see Mel Marquis, 'Idea Merchants and Paradigm Peddlers in Global Antitrust' (2014-15) 28 Pac. Mc George Global Bus. \& Dev. L.J. 155.

6 See n. 2 above.

7 ibid.

8 ibid.

9 ibid.

10 ibid. The provision was as follows: 'The penalty of prison correctional in its minimum period or a fine ranging from 200 to 6,000 pesos, or both, shall be imposed upon: 1 . Any person who shall enter into any contract or agreement or shall take any part in any conspiracy or combination in the form of a trust or otherwise, in restraint of trade or commerce to prevent by artificial means free competition in the market. 2. Any person who shall monopolize any merchandise or object of trade or commerce, or shall combine with any other person or persons to monopolize said merchandise or object in order to alter the price thereof by spreading false rumors or making use of any other article to restrain free competition in the market. 3. Any person who, being a manufacturer, producer, or processor of any merchandise or object of any commerce or an importer of any merchandise or object of commerce from any foreign country, either as principal or agent, wholesaler or retailer, shall combine, conspire or agree in any manner with any person likewise engaged in the manufacture, production, processing, assembling or importation of such merchandise or object of commerce or with any other persons not so similarly engaged for the purpose of making transactions prejudicial to lawful commerce, or of increasing the market price in any part of the Philippines, or any such merchandise or object of commerce manufactured, produced, processed,
} 
they remained in force until 2015, when the Philippines adopted a full-fledged competition law. ${ }^{11}$

The process towards the formation of the Japanese competition law was also straightforward. Once the Allied Powers decided on the need for a competition law in Japan, the United States took the lead. The Supreme Command of the Allied Powers (SCAP) was de facto led by the United States. SCAP brought in Posey T. Kime, who worked for the Antitrust Division of the Department of Justice. Kime elaborated a first draft of what had to become the Japanese competition law. This draft reflected a 'consolidation of the principal provisions of the Sherman, Clayton and Federal Trade Commission Acts'. ${ }^{12}$ Seen against this background, and the unavailability of any other model, this seems to be a natural consequence. From the moment Kime proposed its draft to the adoption of the final Act on the Prohibition of Private Monopolization and Maintenance of Fair Trade (AML), ${ }^{13}$ it took eight months of intense negotiations between the SCAP delegation responsible for the competition law and Japanese bureaucrats. ${ }^{14}$ Even though it is often said that competition law in Japan should be considered an 'alien legacy of a lost war', ${ }^{15}$ it cannot be said that the AML is a product of cut and paste. The AML, for example, concentrates the enforcement power in one organization, the Japan Fair Trade Commission; ${ }^{16}$ does not know triple damages $;{ }^{17}$ and has given a specific meaning to unfair trade practices. ${ }^{18}$

That the United States would be the promoter of competition law ideas in these jurisdictions was inevitable. Besides the political influence the United States had in the region, there was no local intellectual movement that could provide the underpinning of a homegrown competition law.

The world is no longer characterized by dependence. Therefore, each country interested in the adoption of a competition law has to seek its way in this area of the law. This independence, however, does not mean that each country has to reinvent the wheel and start writing a competition law from scratch. These countries will be influenced by other legal regimes. ${ }^{19}$ Unlike the Philippines and Japan, which had only one model legal regime

assembled in or imported into the Philippines, or of any article in the manufacture of which such manufactured, produced, processed, or imported merchandise or object of commerce is used.' See UNCTAD, 'Voluntary Peer Review of Competition Law and Policy: Philippines' (2014), available at: https://unctad .org/en/PublicationsLibrary/ditcclp2014d1_en.pdf (accessed 5 October 2019).

${ }_{11}$ Ditucalan (n. 1 above).

12 John O. Haley, Antitrust in Germany and Japan: The First Fifty Years, 1947-1998 (University of Washington Press 2001) 30-1.

13 Antimonopoly Act (n. 2 above).

14 Haley (n. 12 above) at 30 and 32 (indicating that there was a draft in August 1946 and the adoption of the Antimonopoly Law was in March 1947).

15 ibid., 4.

16 Harry First and Tadashi Shiraishi, 'Concentrated Power: The Paradox of Antitrust in Japan' (2005), available at: https://papers.ssrn.com/sol3/papers.cfm?abstract_id=652505 (accessed 5 October 2019).

17 Simon Vande Walle, Private Antitrust Litigation in the European Union and Japan: A Comparative Perspective (Maklu 2013) 60.

18 Steven Van Uytsel and Yoshiteru Uemura, 'Online Platforms and the Japan Fair Trade Commission: The DeNA Case as an Example of Early Market Intervention' in Björn Lundqvist and Michal S. Gal (eds) Competition Law for the Digital Economy (Edward Elgar 2019), Chapter 8.

19 Mel Marquis, with reference to William Kovavic, expands on this issue and explains that a far greater number of jurisdictions have taken an influential role in the proliferation of competition law: 
to look at, by the time that other Asian countries saw an advantage in the adoption of a competition law the United States was no longer the only model. In contrast to Japan, Germany and Europe were able to create a competition law less influenced by the US. This was enabled by the European intellectual circles who had been contemplating regulatory responses to the new socioeconomic reality that was created by the industrial revolution. ${ }^{20}$ The presence of this movement enabled Germany to take intellectual leadership in development of their competition law. As a result, the German drafting process lasted much longer than the Japanese one, from 1946 to $1957 .{ }^{21}$ But Germany was able to draft a more indigenous competition law. The drafting of the German competition law was, further, a source of inspiration for the competition law provisions in the Treaty of Rome, the treaty establishing what we now know as the European Union (EU). ${ }^{22}$

As the adoption of competition law increasingly became a policy question in Asia over the past four decades, German and EU competition law and practices were able to stand firm as a new model. Equally, Japan, after regaining its sovereignty, was able to give its own twist to the competition law it drafted, with the help of the SCAP. The separate Asian jurisdictions had more models to turn to. Korea, Taiwan and Vietnam have drawn heavily on these three jurisdictions' experience to draft their respective competition laws. ${ }^{23}$ Singapore, Hong Kong, China and Malaysia relied more on European competition law as a model.

Some countries that have received support in the drafting of their competition law or in the development of their enforcement policies, such as Vietnam and Thailand, have also been able to influence other competition law regimes. Due to the sociopolitical and/ or economic characteristics of these countries, Vietnam and Thailand have been attractive to neighbouring countries as systems of study for the writing of other competition laws. Without pursuing a leading role, Thailand and especially Vietnam have therefore been able to transform themselves into competition-related idea merchants and so exert considerable influence in other countries, such as Laos and Myanmar. ${ }^{24}$

\footnotetext{
'China has risen - or pounced, and seems to have the better part of the antitrust world mesmerized. In Japan, the JFTC in the last decade has started to shake free of its dog-that-didn't-bark past and to become a serious, though still idiosyncratic, institution. Competition authorities in, for example, Brazil and South Korea have become very active, and punch above their weight. Australia, another significant antitrust jurisdiction, has had remarkable regional and global influence, the pending "root and branch" review notwithstanding; and for the future, India could potentially become yet another important jurisdiction if the efforts of the Competition Commission can earn it credibility and provoke cultural change. (This will likely take years to accomplish; several factors will have to conspire if the necessary environment is to be created.) Meanwhile, among the EU Member States it is no longer only the Bundeskartellamt that commands attention.' See Marquis (n.5), 165.

20 David J. Gerber, Law and Competition in Twentieth Century Europe: Protecting Prometheus (Oxford University Press 1998).

${ }_{21}$ Haley (n. 12 above) at 48.

22 At that time, the European Economic Community.

23 See Andy C.M. Chen, Chapter 5 of this volume; Yo Sop Choi, Chapter 4 of this volume; and Ly Huong Luu, Chapter 8 of this volume.

24 See Burton Ong, Chapter 9 of this volume; Thomas Cheng, Chapter 10 of this volume; May Fong Cheong et al., Chapter 11 of this volume; and Xiaoye Wang, Chapter 12 of this volume.
} 
Besides being a source for drafting a competition law in other Asian jurisdictions, Japan has also been offering technical assistance in developing enforcement policies. According to Wan Khatina Nawawi,

Vietnam was the top recipient of technical assistance from the JFTC between January 2004 and June 2010, with 103 technical assistance events. Cambodia, Laos and Myanmar respectively participated in seventeen, fifteen, and ten JFTC technical assistance events in the same period. The JFTC has also placed resident advisors at the Vietnamese Competition Authority (VCA) on long-term assignments to train VCA officers on substantive (the content of competition law) and procedural matters (such as investigative techniques). ${ }^{25}$

Japan is definitely not the only Asian country actively engaged in advocating 'competition-related ideas and concepts'. ${ }^{26}$ The Korean Fair Trade Commission (KFTC) has engaged in similar activities. It is documented that the KFTC sends former or current officials to developing countries to provide advice and assistance, ${ }^{27}$ and organizes internship programmes for officials from developing countries. A more recent recipient of this kind of support is the People's Democratic Republic of Laos. Additionally, the Korean Office for International Cooperation is also engaged in organizing competition policy training sessions. Mongolia, among the Asian countries, has taken part in them. Taiwan has mainly focused on Vietnam and Indonesia to provide training courses and dispatch experts. $^{28}$

What then happened to the United States as competition-related idea merchant? Some have stated that the role of the United States model, the sole one immediately after the Second World War, has drastically diminished. 'An antitrust policy that seemed designated to do very little ${ }^{29}$ is not an attractive option for many of the countries seeking to adopt a competition law, according to Daniel Crane. This is shared by Eleanor Fox, who states that the

EU has a more copious view than the U.S of harm to competition. It seeks to preserve competitive rivalry in concentrated markets and to safeguard openness and access (albeit sometimes without a sufficient rudder). Openness of markets is in the DNA of Europe. EU law is more sympathetic to economies that have suffered severe blockage of markets as a result of pervasive state ownership, privilege, cronyism, and discrimination. ${ }^{30}$

Having a myriad of models may be positive. A better choice can be made between what works and what does not, between what is appropriate for your economic structure and

25 Wan Khatina Nawawi, 'Regionalisation of Competition Law and Policy in ASEA: Why, How and When?', in Burton Ong (ed.) The Regionalisation of Competition Law and Policy within the ASEAN Economic Community (Cambridge University Press 2018) 41.

26 Marquis (n. 5 above) 204.

27 Korea Fair Trade Commission, Annual Report 2017 (2017) 171, available at: www.ftc.go.kr/ eng/cop/bbs/selectBoardList.do?key=517\&bbsId=BBSMSTR_000000002404\&bbsTyCode=BBST11 (accessed 5 October 2019).

28 Jinn-Chuan Tang, 'Recent Development of Competition Law and Policy in Taiwan' (2008), available at: www.jftc.go.jp/eacpf/07/07_04_06.pdf (accessed 5 October 2019).

29 Dan Crane, 'Eleanor Fox (New Y̌rk University): Networking the World' (2011) 4 Concurrence 2.

30 Eleanor Fox's answer to Dan Crane, in Crane (n. 29 above) 3. 
what does not, and so on. However, it also requires a meticulous approach towards the adoption of competition law. Without an analysis of why something exists in one jurisdiction or why there are differences between jurisdictions, drafters of competition laws may end up mixing elements from competition laws from different countries. The risk of this evolution will increase when more than one idea merchant has been recommending their respective competition law to a single country. The result of this process may be the fusion of different competition laws. The fusion may not always lead to interpretative problems. For example, a provision on unfair trade practices as understood in the Vietnamese competition law can perfectly complement a provision on agreements as is understood in the European competition law. Fusion will become problematic if diverging concepts are used to regulate similar behaviour. For example, unilateral conduct can be regulated by the European concept of abuse of dominance or by the United States' concept of monopolization. ${ }^{31}$ Even though both concepts regulate the same kind of behaviour, the outcome of both approaches may be different. Similarly, what would happen if you combined the US concept of per se illegality with the European concept of 'object' in order to address price-related agreements $?^{32}$

Legislators should be aware that allowing different idea merchants to advise on the conceptualization of their respective competition laws requires utmost vigilance in relation to the concepts they decide to borrow.

\section{COMPETITION LAW CONVERGING ON ECONOMIC THEORY}

When drafting the Philippine and Japanese competition laws, few questions were raised regarding the theoretical underpinning of competition. Yet, economic theory on competition had been around for centuries. ${ }^{33}$ The lack of this kind of discussion could be reduced to the fact that economic theory has not always been central in the interpretation of competition law. Tracing back the history of the US Sherman Act, one of the oldest competition laws in the world, it can be seen that 'considerations of fairness, economic freedom, equal opportunities, and protection of small and medium-sized firms' ${ }^{34}$ have been thriving throughout the first 70 years of its existence. In fact, economic theory only

31 See Steven Van Uytsel and Somsack Hongvichit, Chapter 14 of this volume.

32 See Alizedney M. Ditucalan, Chapter 13 of this volume.

33 Economic theory on competition is much older than any of the currently existing competition laws. As early as 1776, Adam Smith espoused the idea that competition is the regulatory force keeping prices under control. See Adam Smith, The Wealth of Nations (Cotterie Classics 2016). 'Since the days of Adam Smith, economists have naturally updated their views of competition and have developed various more refined competition models.' See Roger Van den Bergh, Comparative Competition Law and Economics (Edward Elgar 2017) 17. Smith's classical economics has been followed, in chronological order, by price theory, the Ordoliberal School (linked to the Freiburg School), the Harvard School, the Chicago School, competition as a dynamic process, the theory of contestable markets, the transaction cost approach, modern industrial organization, and behavioral antitrust economics. See, e.g., Roger J. Van den Bergh and Peter D. Camesasca, European Competition Law and Economics: A Comparative Perspective (2nd ed., Sweet and Maxwell 2011) 54-104; Doris Hildebrand, The Role of Economic Analysis in the EC Competition Rules (3rd ed., Wolters Kluwer Law \& Business 2009) 95-184.

34 Van den Bergh (n. 33 above) at 101. 
started to take an increasing role in the interpretation of US competition law with the insights of the Harvard School, which held that the structure of the market influences the conduct of firms, which in turn determines the performance of an industry. ${ }^{35}$

A real shift in the recognition of a 'diversified and fragmented set of policy goals' ${ }^{36}$ came in the 1970s, with the rise of the Chicago School. With the increasing influence of the Chicago School, 'moral and social goals disappeared from the policy discussion'37 in the United States. Instead, everything started to revolve around the concept of total welfare and 'micro-economic's8 tools to give context to that concept. The policy debate was gradually embraced by the US Supreme Court, which 'has evolved from a multiple goals perspective to a pure economic welfare approach, focusing on all types of economic efficiency (static efficiency, dynamic efficiency and their potential trade-offs)'. ${ }^{39}$ The United States' choice to be driven by the insights of the Chicago School in the interpretation of its competition laws had implications. It is well documented that a Chicago School analysis will render different results in relation to vertical agreements, unilateral conduct and concentrations. ${ }^{40}$ Therefore, a similar case could be judged differently in the United States and in another jurisdiction, possibly leading to dissatisfaction between enforcement agencies of different countries. In the end, 'in the early days of European competition law the European Commission often tried to divorce itself from decisions based upon economic thinking' ${ }^{41}$ and tried to justify it by saying 'the lack of precise economic analysis may undermine the foundations of competition law'. ${ }^{42}$

Scholars identified the potential for conflict at a very early stage and therefore condemned the EU for not embracing an economic approach. ${ }^{43}$ Anne Witt notes Barry Hawk's denouncement of the EU's competition law enforcement on vertical agreements as 'too legalistic and lacking economic analysis'. ${ }^{44}$ The EU's approach to unilateral conduct, another area of competition law where economic analysis was lacking, was the subject of many more papers, the common thread of which was that the EU analysis in several unilateral conduct cases had led to unsatisfactory results if taking economic theory into consideration. ${ }^{45}$ Academic warnings did not shift the EU competition policy towards economic theory. Other factors contributed to that. Important factors contributing to a more positive EU stance towards economic theory for the analysis of competition law cases included a series of transatlantic conflicts about different outcomes in competition law cases in the late 1990s and early 2000s, ${ }^{46}$ several differing opinions by the Court of Justice
ibid., 102.
ibid., 101.
ibid., 102.
ibid., 103.
ibid., 104.
See, e.g., ibid., 103.
$41 \quad$ Van den Bergh and Camesasca (n. 33 above) 12.
43 See, e.g., Anne C. Witt, The More Economic Approach to EU Antitrust Law (Hart Publishing
2016) 10-11 (especially the literature cited in footnotes 10-12).
44 ibid., 10; the work summarized by Witt: Barry E. Hawk, 'System Failure: Vertical Restraints and EC Competition Law' (1995) 32 CMLR 973; Barry E. Hawk, 'The American (Anti-Trust) Revolution: Lessons for the EEC?' (1988) 9 ECLR 53.
45 Witt (n. 43 above), at 11.

42 ibid., 13.

46 ibid. 
regarding the decisions made by the Commission, ${ }^{47}$ and the appointment of an economist as Commissioner for Competition Policy. ${ }^{48}$

Even though the debate on competition law's convergence with economic theory was mainly a transatlantic one, ${ }^{49}$ it had an impact on the shaping of competition law elsewhere. Having begun in the early 1980s, this debate was by far the most evolved by the time that many of the new competition laws were to be developed. Besides, the EU was also carefully moving in the direction of economic theory. In these kinds of circumstances, reference to economic theory is almost unavoidable when a country is advised on the adoption of a competition law.

That this actually happened can be deduced from a quote from David Gerber, who suggests that 'decision-makers may find the idea of using economics in competition law attractive in the abstract, not least because foreign advisors urge its importance' ${ }^{50}$ In hindsight, Gerber judged this advice as potentially inappropriate. The countries that received the advice to enclose economic theory into their competition law were 'likely ... unsure of how they can apply an (economic-based model) in their own competition law system'. ${ }^{51}$

One of the reasons behind the inappropriateness of advising as to economic theory may be the lack of human or financial resources. Economic analysis of competition law problems requires a specific set of knowledge and skills, which is not necessarily transferrable through short term training courses. These kinds of courses would most likely focus on transferring 'experience developed in economically advanced countries'. ${ }^{52}$ If domestic expertise were available, Gerber points out that such expertise does not come for free: these experts have to be hired by the enforcement agency and be given full support to do meaningful work, such as providing 'extensive access to relevant data ... and computing

47 ibid.

48 ibid.

49 The difference in competition law has been described as a transatlantic conflict. See ibid., 11. In relation to Japan, the debate was mainly on forcing Japan towards a more effective enforcement of its competition law. See, e.g., Harry First, 'Antitrust Enforcement in Japan' (1995) 64 Antitrust L.J. 137. On an international level, the discussion was more on convergence around substantive law provisions. See, e.g., Daniela Kröll, Toward Multilateral Competition Law? After Cancún: Reevaluating the Case for Additional International Competition Rules under Special Consideration of the WTO Agreement (Peter Lang 2007); Thilo Reimers, Probleme und Perspectiven der Internationalisierung des Wettbewerbsrechts (Nomos 2007); Kevin C. Kennedy, Competition Law and the World Trade Organisation: The Limits of Multilateralism (Sweet \& Maxwell 2001); Roger Zäch (ed.), Towards WTO Competition Rules: Key Issues and Comments on the WTO Report (1998) on Trade and Competition (Stæmpfli Publisher 1999); Wolfgang Fikentscher and Ullrich Immenga (eds), Draft International Antitrust Code (Nomos 1995); Wolfgang Fikentscher, 'A Transnational Antitrust Convention and the Recent European Antitrust Proposals: Exercises in Economic Anthropology' in Clifford Jones and Matsuo Matsushita (eds) Competition Policy in the Global Trading System: Perspectives from the EU, Japan and the USA (Kluwer Law International 2002) 364; Wolfgang Fikentscher, 'On the Proposed International Antitrust Code' in John O. Haley and Hiroshi Iyori (eds) Antitrust: A New International Trade Remedy? (Pacific Rim Law \& Policy Association 1995) 345; Wolfgang Fikentscher, 'Competition Rules for Private Agents in the GATT/WTO System' (1994) 49 Aussenwirtschaft 281.

50 David J. Gerber, 'Adapting the Role of Economics in Competition Law: A Developing Country Dilemma' in Michal S. Gal et al. (eds) The Economic Characteristics of Developing Jurisdictions: Their Implications for Competition Law (Edward Elgar 2015) 248.

51 ibid.

52 ibid., 253. 
and other support functions'. ${ }^{53}$ The financial burden thus goes well beyond the personnel costs of hiring experts in economic theory. Another possibility is to engage external expertise.

Whether internal or external expertise is called upon, the kind of economic theory may contribute to another reason why it is inappropriate to advise as to its incorporation in competition policy. At the initial stage of the debate about the convergence on economic theory, the advice regarding the question 'what kind of economic theory' would have been to look at Robert Bork's suggested answer to his statement: 'Antitrust policy cannot be made rational until we are able to give a firm answer to one question: What is the point of the law - what are its goals? ${ }^{54}$ Bork had a single goal in mind: consumer welfare. Leaving aside the existing criticism of Bork's understanding of consumer welfare, he was instrumental in launching the Chicago School of Economics, ${ }^{55}$ which has been influential in the debate about convergence on economic theory for more than two decades. This influence can also be noted in the debate on Asian competition laws. Taiwan, for example, decided to abandon the per se treatment of vertical price fixing agreements in favour of the approach elaborated by the Chicago School of Economics. ${ }^{56}$

The Chicago School of Economics' approach on vertical agreements is questionable, and a more recent trend in the literature distances itself from the Chicago School religion. ${ }^{57}$ The call for recognition that "there is no such thing as "the" economic approach to competition law, which offers exact and authoritative answers to all kinds of competition law problems', ${ }^{58}$ was initiated by the fact that there exist varieties of capitalism. This has led to the insight that:

There is no best way to organize and govern capitalism and, notwithstanding claims about long-term convergence, several varieties of capitalism persist due to the heterogeneity of goods and services ... produced for sale, and due to the inevitable embedding of capitalist production and markets in broader sets of social relations. Such variation is evident in the wide range of firms, industries and sectors, complexes and clusters, local and regional associations, national economies, plurinational systems, transnational networks, and trading blocs found in capitalist environments. Advocates of a one-size-fits-all model of competition law ... tend to ignore

\footnotetext{
53 ibid.
}

54 Robert H. Bork, The Antitrust Paradox: A Policy at War with Itself (The Free Press 1978) 48.

55 Oliver E. Williamson, reviewing Robert H. Bork, The Antitrust Paradox: A Policy at War with Itself (Basic Books 1978), 'Review' (1979) 46 U. Chicago L. Rev. 526.

56 See Andy C.M. Chen, Chapter 5 of this volume.

57 See David Gerber, 'Competition Law: Convergence in Uncertainty - Are We Where We Thought We Were? (2017), available at: https://papers.ssrn.com/sol3/papers.cfm?abstract_id=2987002 (accessed 5 October 2019). Gerber mentions that the convergence debate around one standard would be difficult to reach. He therefore suggests 'branched convergence', which means that 'competition law systems would continue to recognize the potential value of the existing convergence model, but each would also seek to adapt the core principles of this model to its own political and economic circumstances. The convergence model would continue to "feed" individual "branches", and experience with it would in turn enrich its value by identifying both its effectiveness and its limits under specific circumstances. In this context, "leadership" of the process becomes less important and integrating experience from varying contexts becomes more important.'

$58 \quad$ Van den Bergh (n. 33 above) at 15. 
this diversity - especially where the model for this derives from liberal market economies themselves. ${ }^{59}$

The above quoted text forms part of a paragraph that concludes with the observation that the different varieties of capitalism call for different forms of competition law. ${ }^{60}$ Despite recognition of this issue by practitioners and in a growing body of literature, what it meant for economic theory has long been neglected. In a series of articles on the role of economics in the competition law of developing countries, Gerber explains how economic theory should adapt to the shifting paradigm in competition law. ${ }^{61}$ Rather than advocating for a US-inspired economic theory, Gerber instructs us to look at areas of economics that are more suitable for the conditions of countries to which economic theory is recommended. ${ }^{62}$ Singapore, for example, has embraced a different welfare standard than the one applicable in the United States. As a result, vertical agreements are excluded from the scope of competition law. Further, economic benefits could be the basis for allowing exemptions without the need to distribute them to consumers. ${ }^{63}$

Gerber expands on the issue of contextualizing the economic theory and does it within the context of developing countries. He indicates that for developing countries, developmental economics, institutional economics and behavioural economics could be more instrumental than other economic theories. ${ }^{64}$ If the advice is to adhere to the conventional economic theory, Gerber suggests not to pursue a full application of the economic theory. ${ }^{65}$ Again in the context of developing countries, the scope of application of the economic theory could be reconsidered, the intensity of the use of the economic theory could be reduced or the role of the economic theory could be modified. ${ }^{66}$

What Gerber suggests is the end result of an evolution which started with questioning the convergence of competition law around one standard: the Chicago School of Economics. However, before alterations of or alternatives to the conventional economic theory were suggested, the competition law community experienced two different evolutions further strengthening the view about the need for diversity in competition law. The first was brought about by the International Competition Network, while the second was advocated for by scholars discussing competition law in the context of economies in transition or developing countries.

59 Bob Jessop, 'The Complexities of Competition and Competitiveness: Challenges for Competition Law and Economic Governance in Variegated Capitalism' in Michael W. Dowdle, John Gillespie, and Imelda Mehra (eds) Asian Capitalism and Regulation of Competition Law: Towards a Regulatory Geography of Global Competition Law (Cambridge University Press 2013) 96, 111.

60 ibid.

${ }_{61}$ Gerber (n. 57 above) at 255-60.

62 ibid, 258-60.

63 See Burton Ong, Chapter 9 of this volume.

64 Gerber (n. 57 above) at 257.

65 ibid., 257.

66 ibid., 257-8. 


\section{THE INTERNATIONAL COMPETITION NETWORK: AN IDEA MERCHANT FOR DIVERGENCE BUT WITH A BIAS TOWARDS EXPERIENCED ENFORCEMENT AGENCIES}

Divergence has not always received full support among the older enforcement agencies. In 1982, for example, William Baxter, then head of the Antitrust Division of the Department of Justice (DOJ), met with the head of the Commission's Directorate-General for Competition to discuss a potential divergent outcome of the respective enforcement agency's investigation into the behaviour of IBM. The worry that drove Baxter's action was that the Commission was about 'to order IBM to disclose computer interface specifications, a remedy that Baxter thought was unwarranted' ${ }^{67}$ This disclosure order would extend beyond the territory of the then European Community. In other words, the European Commission would not have been able 'to localize the effects of what they do'. ${ }^{68}$ Whereas the immediate response to this tension was to set up different channels of communication across the Atlantic and elsewhere, ${ }^{69}$ the European Commission's differing treatment of the acquisition of McDonnell Douglas by Boeing and of Honeywell by General Electric showed that a new approach towards global competition issues had to be found. This approach was the foundation of a transnational body aimed at understanding divergence, in order to eventually reach convergence.

The initial step towards this transnational body was taken by the US DOJ. In order to advise and assist the US DOJ in looking for the 'new tools, tasks and concepts that will be needed to address the competition issues that are just arising on the horizon of the global economy', ${ }^{70}$ the International Competition Policy Advisory Committee (ICPAC) was established in 1997. ${ }^{71}$ Besides the Committee chairpersons, James Rill and Paula Stern, and its executive director, Merit Janow, seven business and foundation executives and three professors took part in the hearings, deliberations and formulation of recommendations. ${ }^{72}$ Three years after its establishment, ICPAC submitted a report to Attorney General Reno and Assistant Attorney General Klein. ${ }^{73}$ This report contained numerous recommendations, one of which was the establishment of a Global Competition Initiative (GCI). ${ }^{74}$

${ }^{67}$ Harry First, 'Evolving toward What? The Development of International Antitrust' in Josef Drexl (ed.) The Future of Transnational Antitrust - From Comparative to Common Competition Law (Kluwer Law International 2003) 23, 24.

68 ibid.

69 Focusing only on the binding bilateral instruments, three different types of agreements have been concluded. One type of agreement seeks to avoid and manage jurisdictional disputes between national competition enforcement authorities. Another type of agreement relates to cooperation of competition law enforcement. Still another type of agreement deals with technical cooperation. Kevin C. Kennedy, Competition Law and the World Trade Organisation: The Limits of Multilateralism (Sweet \& Maxwell 2001) 42.

70 See Eleanor Fox, 'Linked-In: Antitrust and the Virtues of a Virtual Network' in Paul Lugard (ed.), The International Competition Network at Ten: Origins, Accomplishments and Aspirations (Intersentia 2011) $105,113$.

${ }^{71}$ First (n. 67 above) at 33.

72 See ibid.

73 See Fox (n. 70 above) at 114.

74 See ibid. 
It was Assistant Attorney General Klein who took the initiative to launch the proposal at the international level. At the Tenth Anniversary Conference for European Merger Control, Joel Klein indicated that the bilateral efforts were not a sufficient answer to the problems caused by globalization. There should also be a focus on the substantive part of competition law. However, he acknowledged that there was not a forum suitable for this job. ${ }^{75}$ Inspired by the proposal to set up a GCI, Klein called for an initiative at the global level, something that may eventually pave the way for multilateralism within the field of competition law. ${ }^{76}$

Even though the idea for a GCI was positively welcomed, the contours of this initiative had still to be drawn. At a meeting in Ditchley Park, organized by the International Bar Association with support from the American Bar Association Antitrust Law Section and the Fordham Corporate Law Institute, ${ }^{77}$ it became clear that the government agencies wanted to take control of the GCI. ${ }^{78}$ However, without US support, it was unclear whether the GCI would be a viable initiative. As early as the Ditchley Park meeting, there was no certainty on whether the newly inaugurated President George Bush and his administration would back the initiative. ${ }^{79}$

Attracted by the idea that the new initiative would only cover competition law and focus on issues for which solutions would be achievable, the newly appointed Assistant Attorney General, Charles James, and Timothy Muris, newly appointed to the position of Chairman of the Federal Trade Commission, were eager to support the GCI ${ }^{80}$ Once this support was ascertained, further consensus was sought among other competition law enforcement authorities. By the time that the Fordham International Antitrust Conference was held in 2001, this consensus had been achieved among 14 jurisdictions. ${ }^{81}$ The enforcement authorities of these 14 jurisdictions used the opportunity of the Fordham Conference to launch the initiative, and named it the International Competition Network (ICN). ${ }^{82}$

The ICN has, since its establishment, aimed at 'addressing antitrust enforcement and policy issues of common interest and formulate proposals for procedural and substantive

75 See First (n. 67 above) at 33.

76 See Fox (n. 70 above) at 114.

77 See International Competition Network (ICN), 'About', available at: www.internationalc ompetitionnetwork.org (accessed 5 October 2019).

78 See Fox (n. 70 above) at 114.

79 See ibid.

80 See ibid.

${ }_{81}$ See ICN (n. 77 above) (Australia, Canada, European Union, France, Germany, Israel, Italy, Japan, Korea, Mexico, South Africa, United Kingdom, United States and Zambia).

82 See, e.g., Paul Lugard (ed.), The International Competition Network at Ten: Origins, Accomplishments and Aspirations (Intersentia 2011); Harry First, 'Evolving toward What? The Development of International Antitrust', in Josef Drexl (ed.), The Future of Transnational Antitrust From Comparative to Common Competition Law (Stæmpfli Publisher 2003) 23. For general discussion on the development of transnational organizations, such as the International Competition Network, see Anne-Marie Slaughter, A New World Order: Government Networks and the Disaggregated State (Princeton University Press 2004); Pierre-Hugues Verdier, 'Transnational Regulatory Networks and Their Limits' (2009) 34 Yale Journal International Law 113; Kal Raustiala, 'The Architecture of International Cooperation: Trans-Governmental Networks and the Future of International Law' (2002) 43 Virginia Journal of International Law 1. 
convergence through a result-orientated agenda and structure' ${ }^{83}$ The idea of convergence has been complemented by encouragement of 'the dissemination of antitrust experiences and best practices ${ }^{94}$ and promotion of the 'advocacy role of the antitrust agencies' ${ }^{85}$ The initial aim was restated in the Operational Framework that the Steering Committee formulated in 2012. ${ }^{86}$ The ICN's website incorporates a short restatement of this mission statement. In what it calls its mission statement, in a prominent position on the ICN website, the ICN advocates 'the adoption of superior standards and procedures in competition policy around the world, formulate proposals for procedural and substantive convergence, and seek to facilitate effective international cooperation to the benefit of member agencies, consumers and economics worldwide'. ${ }^{87}$ Convergence has been further elaborated by the ICN Steering Committee, which defined it as the 'voluntary adoption of widely-accepted norms of competition policy, substantive standards, procedures and levels of institutional capacity', ${ }^{88}$

Inherent in the concept of convergence is divergence. One can only move in the direction of widely accepted standards if the current practices are different from each other. Convergence, as has been identified by Maurice Stucke, can only occur if there is an agreement on norms, standards and procedures that have been divergent in the past. ${ }^{89}$ This is also reflected in the ICN's vision on the second decade. Convergence is described as running through three different stages. The first stage towards convergence is the implementation of different norms, standards and procedures. This will allow for experimentation to see which of these norms, standards and procedures are more effective than others. Sharing the information and experiences stemming from the experimentation is the second stage. This part of the process will facilitate the identification of best practices, which could be then put forward as the benchmark..$^{90}$ The role of the ICN in this evolutionary process is to 'promote the flow of information about different agencies' ongoing experiments and feedback from these experiments'. ${ }^{91}$ The third stage is that individual jurisdictions opt for the benchmark, the norm that has received consensus as being the best possible solution for specific problems..$^{92}$

83 International Competition Network (ICN), Memorandum on the Establishment and Operation of the International Competition Network (2001), available at www.internationalcompetitionnetwork.org/ uploads/library/doc579.pdf (accessed 5 October 2019).

84 ibid.

85 ibid.

86 See ibid.

87 See ICN (n. 77 above); see also Imelda Maher and Anestis S. Papadopoulos, 'Competition Agency Networks around the World' in Ariel Ezrachi (ed.) Research Handbook on International Competition Law (Edward Elgar 2012) 60, 74.

$88 \quad \mathrm{ICN}(\mathrm{n} .83$ above) at 5.

89 Maurice E. Stucke, 'Greater International Convergence and the Behavioral Antitrust Ambit' in Ariel Ezrachi (ed.) Research Handbook on International Competition Law (Edward Elgar 2012) 115, 158.

90 Hugh M. Hollman, William E. Kovavic and Andrew S. Robertson, 'Building Global Antitrust Standards: The ICN's Practicable Approach' in Ariel Ezrachi (ed.) Research Handbook on International Competition Law (Edward Elgar 2012) 89, 92; Stucke (n. 89 above) at 158.

91 Stucke (n. 89 above) at 158.

$92 \operatorname{ICN}($ n. 83 above) at 5-6. 
With its view on convergence, the ICN has made it acceptable for competition law regimes to diverge from each other. This view is helpful for countries seeking to adopt a competition law. By reading the ICN documents, drafters of a new competition law will learn that there could be different solutions for dealing with competition-related issues. However - and this contributes to the complexity - the ICN's documents should be read and studied carefully. The reason: mature enforcement agencies are the main driver behind the ICN's activities and policy setting. ${ }^{93}$

The ICN is a nonexclusionary organization, allowing each enforcement agency to become a member, ${ }^{94}$ and giving each member the opportunity to fully participate. ${ }^{95}$ However, Yane Svetiev indicates that the best practice selection in the ICN is likely to be affected by a minoritarian bias. ${ }^{96}$ Financially well-resourced enforcement agencies, which are often the more mature ones, have greater possibilities to influence the agenda setting. Once issues are on the agenda, other problems arise. Less mature enforcement agencies may not have enough experience to discuss and evaluate the proposals. ${ }^{97}$ Very often there already exists a consensus over the issues that have been put on the agenda, so that no profound discussion takes place..$^{98}$ In some cases, the issues on the agenda are not salient to the majority of the jurisdictions and therefore they do not even participate in the discussion. ${ }^{99}$

With the well-resourced enforcement agencies being the driving force, it can be argued that the ICN was in reality a substitute for the main competition-related idea merchants. Svetiev has posited that this, as such, should not be a problem. The ICN's task is not to look for a well-suited solution to a specific problem, but for experiences, substantive or procedural, that work in other jurisdictions. ${ }^{100}$ After identifying these and putting them

93 See Hugh M. Hollman and William E. Kovavic, 'The International Competition Network: Its Past, Current and Future Role' in Paul Lugard (ed.) The International Competition Network at Ten: Origins, Accomplishments and Aspirations (Intersentia 2011) 51, 58 (indicating that without support of the wealthy agencies, the ICN would have collapsed).

94 Fox (n. 70 above) at 125.

95 ibid., 125; Maher and Papadopoulos (n. 87 above) at 85.

96 Neil Komesar has pointed out that the more agencies participate and the more complex the issue at stake, there is an 'enhanced possibility of minoritarian bias and the prospect of "rent-seeking". The ideas or interests of the majority risk being underrepresented. Neil K. Komesar, Law's Limits: The Rule of Law and the Supply and Demand of Rights (Cambridge University Press 2001) 153. Another point of critique on the participation within the ICN is on the bias towards the more mature and richer competition jurisdictions. The financially restrained agencies will face difficulties organizing workshops or the annual conference. This in turn may jeopardize their chances of becoming a member or chair of the Steering Group or the chair of a Working Group. With less chance of being a member of the Steering Group, these financially restrained agencies will have less power to influence the agenda setting of the ICN. Further, due to the fact that they will most likely not be chairing a Working Group, these agencies will also not be the ones holding the pen when the first drafts of the recommended practices are written. See Hollman and Kovavic (n. 93 above) 58.

97 Fox (n. 70 above) at 126. See also Daniel D. Sokol, 'Monopolists without Borders: The Institutional Challenge of International Antitrust in a Global Gilded Age' 107 (Legal Studies Research Paper Series, Paper No. 1034, 2007), available at: ssrn.com/abstract=961380 (accessed 5 October 2019).

98 See Yane Svetiev, 'Partial Formalization of the Regulatory Network' (2007), available at: http:// papers.ssrn.com/sol3/papers.cfm?abstract_id=1564890\&download=yes. (accessed 5 October 2019).

99 ibid.

100 ibid, 35. 
forward as best practices, legislators considering the adoption of a competition law or enforcement agencies looking for solutions to their problems should transform these experiences to suit the task and the local environment in which they are supposed to operate. Yet, how should an inexperienced legislator or enforcement agency modify the ideas put forward by the ICN best practices if no guidelines are given. Another concern with the operation of the ICN is that no one really tells the inexperienced legislator or enforcement agency whether the best practices could be taken for granted. In other words, for a long time, the ICN has had no internal critical review system of best practices.

\section{DO NOT BLINDLY FOLLOW THE COMPETITION-RELATED IDEA MERCHANTS}

By the time that the ICN cleared the way for divergence, several countries had already adopted a competition law. In the end, 'competition law [had] ... become a fashion'101 and 'to be someone, it appears, everyone ... must have a competition statute'. ${ }^{102}$ These statements were made around the time that Eastern European countries were required to have a competition law 'on the books as well as the additional façade of a nominal enforcement authority in charge ${ }^{\prime 103}$ in order to be part of the European project. Against the backdrop of the changing ideas on competition law, scepticism has grown towards these new competition laws. John Haley has even expressed the view that the adoption of several of these competition laws could be seen as a wasted effort. Haley justifies this view with the following words:

The problem ... is misplaced reliance on inappropriate models. Simply stated, the legislative paradigms used for national competition legislation throughout the region do not adequately address the basic underpinnings of monopoly power and barriers to free and competitive markets in East Asia or in most other developing states. Nor, some might add, can these models be reasonably transplanted into legal systems that lack the institutional and cultural infrastructures necessary for their effective implementation. ${ }^{104}$

The idea that competition law, as a legal transplant, should be moulded according to the needs of its receiving country has gained momentum in the literature on competition law and developing countries. ${ }^{105}$ To make that point, the literature has often used Godek's

101 John O. Haley, 'Competition Law for the Asia-Pacific Economic Cooperation Community: Designing Shoes for Many Sizes’ (2002) 1 Wash. U. Global Stud. L. Rev. 1, 2.

102 ibid.

103 ibid., 2.

104 John O. Haley, 'Competition Law for East Asia' (2004) 3 Wash. U. Global Stud. L. Rev. 277.

105 The main part is on developing countries. See Michal S. Gal et al. (eds), The Economic Characteristics of Developing Jurisdictions: Their Implications for Competition Law (Edward Elgar 2015); D. Daniel Sokol, Thomas K. Cheng, and Ioannis Lianos (eds), Competition Law and Development (Stanford Law Books 2013); Josef Drexl et al. (eds), Competition Policy and Regional Integration in Developing Countries (Edward Elgar 2012); Umut Aydin and Tim Buthe, 'Competition Law \& Policy in Developing Countries: Explaining Variations in Outcomes; Exploring Possibilities and Limits' (2016) 79 Law and Contemporary Problems 1; Dina I. Waked, 'Adoption of Antitrust Laws in Developing Countries: Reasons and Challenges' (2016) 12 J.L. Econ \& Pol'y 193; Dina I. Waked, 'Antitrust Goals in Developing Countries: Policy Alternatives and Normative Choices' (2015) 38 Seattle University 
comment: 106 'Exporting antitrust ... is like giving a silk tie to a starving man. It is superfluous; a starving man has much more immediate needs. And if the tie is knotted too tightly he won't be able to eat what little there is available to him.' ${ }^{107}$

The first part of this quote has attracted a great deal of criticism, but the second is an expression of the need to internalize something that is foreign to the legal system. It is from this perspective that Mor Bakhoum wrote that '[w]ith the current trend of an ever-increased internationalization of antitrust and increased convergence around western antitrust principles, one must ask whether developing countries should be mere followers or should they step back and define antitrust principles adapt to their specific situation'. ${ }^{108}$

Law Review 945; Michal S. Gal and Eleanor M. Fox, 'Drafting Competition Law for Developing Jurisdictions: Learning from Experience' (2014) New York University Law and Economics Working Papers: Paper 374; Eleanor M. Fox, 'Imagine: Pro-Poor(er) Competition Law: The Role of Competition Law and Policy in Helping to Empower the Poorer Populations of the World' (OECD 2013), available at: http://search.oecd.org/officialdocuments/publicdisplaydocumentpdf/?cote=DAF/COMP/GF(2013)4 $\&$ docLanguage $=$ En (last accessed 5 October 2019); Eleanor M. Fox, 'Competition, Development and Regional Integration: In Search of a Competition Law Fit for Developing Countries' in J. Drexl et al. (eds) Competition Policy and Regional Integration in Developing Countries (Edward Elgar 2012) 273; Maher Dabbah, 'Competition Law and Policy in Developing Countries: A Critical Assessment of the Challenges to Establishing an Effective Competition Law Regime' (2010) 33(3) World Competition 457; Philippe Brusick and Simon J. Evenett, 'Should Developing Countries Worry about Abuse of Dominant Power?' (2008) 2 Wisconsin Law Review 269; Dina I. Waked, 'Competition Law in the Developing World: The Why and How of Adoption and Its Implications for International Competition Law' (2008) 1 Global Antitrust Rev. 69; Michal Gal, 'The Ecology of Antitrust: Preconditions for Antitrust Enforcement in Developing Countries' in P. Brusick et al. (eds) Competition, Competitiveness and Development: Lessons from Developing Countries (UNCTAD 22 2004). Some of the literature extends the issue to countries in transition and small economies: see, e.g., Michal S. Gal, Competition Policy for Small Market Economies (Harvard University Press 2003); Frank Emmert, 'How to and How Not to Introduce Competition Law and Policy in Transitional and Developing Economies' (2011), available at: http:// ssrn.com/abstract=1951609 (accessed 5 October 2019); William E. Kovacic, 'Institutional Foundations for Economic Legal Reform Transition Economies: The Case of Competition Policy and Antitrust Enforcement' (2001) 77 Chi.-Kent L Rev. 265; William E. Kovacic, 'Merger Enforcement in Transition: Antitrust Controls on Acquisitions in Emerging Economies' (1998) 66 U. Con. L. Rev. 1075; William E. Kovacic, 'Getting Started: Creating New Competition Policy Institutions in Transition Economies' (1997) 23 Brook. J. Int'l L. 403; William E. Kovacic, 'Designing and Implementing Competition and Consumer Protection Reforms in Transitional Economies: Perspectives from Mongolia, Nepal, Ukraine, and Zimbabwe' (1995) 44 DePaul L. Rev. 1197; Carolyn Brzezinski, 'Competition and Antitrust Law in Central Europe: Poland, The Czech Republic, Slovakia and Hungary' (1994) 15 Mich. J. Int'l Law 1129.

106 This quote has, for example, been cited by Michal S. Gal and Eleanor M. Fox, 'Drafting Competition Law for Developing Jurisdictions: Learning from Experience' in Michal S. Gal et al. (eds) The Economic Characteristics of Developing Jurisdictions: Their Implications for Competition Law (Edward Elgar 2015) 296, 297; Mor Bakhoum, 'Reflections on the Concepts of "Economic Freedom", "Free Competition" and "Efficiency" from the Perspective of Developing Countries' in Daniel Zimmer (ed.) The Goals of Competition Law (Edward Elgar 2012) 408, 440; William E. Kovacic, 'Designing and Implementing Competition and Consumer Protection Reforms in Transitional Economies: Perspectives from Mongolia, Nepal, Ukraine, and Zimbabwe' (1995) 44 DePaul L. Rev. 1197, 1200 n. 9.

107 Paul E. Godek, 'One U.S Export Eastern Europe Does Not Need' (1992) 15 Regulation - The CATO Review of Business and Government 21.

108 Mor Bakhoum, "Reflections on the Concepts of "Economic Freedom", "Free Competition" and "Efficiency" from the Perspective of Developing Countries' in Daniel Zimmer (ed.) The Goals of Competition Law (Edward Elgar 2012) 408, 439. 
The message of the competition law and developing countries literature is clear. Do not blindly follow competition-related idea merchants, especially if they are suggesting a cut and paste model. Countries willing to adopt a competition law should be sceptical of advice of 'wholesale copying or partial importation from established competition rules'. ${ }^{109}$ The literature requires the countries planning to adopt a competition law to make an assessment. In principle, this should happen for each country. Upon the analysis, the drafters should mould the competition law to fit the situation in their respective country's needs. There is one caution. In the process of drafting, not all knowledge gained by mature competition law regimes should not be thrown away. It could be helpful to stick to well-accepted terminology in order to avoid enforcement problems and so evade Mongolia's experience. Mongolia had reconceptualized the meaning of cartel and dominant position, causing confusion and controversies at the enforcement stage. ${ }^{110}$

To achieve a locally formulated competition law, William Kovavic suggests that outside technical advisors should cooperate with indigenous experts. ${ }^{111}$ The synergy this creates has been summarized by Heba Shaheen as follows:

the strongest draft law is the one where the principles emerge from the recommendations of local experts from the borrowing countries who have a command of the market's need, and which is illuminated by the experiences of other foreign competition laws. This is to ensure an understanding of the needs of the markets, while knowledge and experience of developed competition rules can be addressed during the borrowing process. ${ }^{112}$

The collaborative process between outside technical advisors and local experts may seem easily achievable. However, there are several elements that could jeopardize the process.

First, whether the collaboration aims at achieving a contextualized or a tailormade competition law, the process may take a long time. ${ }^{113}$ A country's characteristics have to be mapped before a valuable assessment could be made on how to formulate the competition law. The mapping could be complicated. There is no template for this exercise. On a general level, Michal S. Gal and Eleanor M. Fox provide an identification of four characteristics that may have to be mapped. ${ }^{114}$ These characteristics are related to economics, institutions, politics and sociocultural elements. Each of these characteristics may require further elaboration. The economic characteristics of a country could relate to the ideology and methodology of market control, barriers to trade, the vulnerability of the market and wealth distribution. ${ }^{115}$ A country's institutional characteristics may link to a shortage of human and financial resources, but more generally also to the lack of institutions to

109 Heba Shahein, 'Designing Competition Laws in New Jurisdictions: Three Models to Follow' in Richard Whish and Christopher Townley (eds) New Competition Jurisdictions: Shaping Policies and Building Institutions (Edward Elgar 2012) 45.

${ }^{110}$ UNCTAD, 'Voluntary Peer Review of Competition Law and Policy: Mongolia' (2012) 16-17, available at: https://unctad.org/en/PublicationsLibrary/ditcclp2012d2_Mongolia_report_en.pdf (accessed 5 October 2019).

111 Kovavic (n. 106 above) at 1215.

112 Shahein (n. 109 above) at 56.

113 ibid.

$114 \mathrm{Gal}$ and Fox (n. 106 above) at 304-11.

115 ibid., 306. 
guide market activity, such as financial institutions or well-functioning courts. ${ }^{116}$ For politics, Gal and Fox refer to the oft-cited problems of political stability and corruption. ${ }^{117}$ Political instability takes away the attention of the government from problems related to the market. Corruption could create barriers for firms outside the influence sphere of the political elite. ${ }^{118}$ For the sociocultural characteristics, Gal and Fox state that there may be a conflict between competitive values and other cultural values of the community, that the notion of competition may have a different meaning among cultures or that competition may be less valued than collaboration. ${ }^{119}$

Second, even if the experts succeed in elaborating an understanding of the country's characteristics and attach the necessary legislative implications to these characteristics, the well-balanced draft can be torn apart by different interests or misunderstandings once it enters the legislative process. ${ }^{120}$ The Philippines had a consistent draft when it went to the legislative process. During the legislative process, two drafts, one based on the US competition laws and one on the European competition law provisions, were mingled. The result: a complex provision to deal with agreements. What could have been an easily implementable provision became something unnecessarily complex, so that one can wonder whether it is consistent with the scholarship to advocate not making competition overly complex for new competition law regimes.

Third, by adapting existing competition laws or tailoring a competition law to a country's context, the enforcement of the competition law may end up in a trial and error situation. Above, we referred to the example of Mongolia, which tried to redefine the cartel and abuse of dominance. ${ }^{121}$ Combining, for example, abuse of dominance and monopolization provisions in one competition law, as happened in the Lao People's Democratic Republic, creates uncertainty as to how the enforcement will play out. ${ }^{122}$

\section{ASEAN AND ITS TURN TO THE EUROPEAN COMPETITION-RELATED IDEA MERCHANT}

The proliferation of competition laws in many of the South-East Asian countries originated from a call by ASEAN to enact national competition law. ASEAN, established in 1967 as a regional intergovernmental organization, ${ }^{123}$ has developed from an organization dealing with political tension in the region of the five original member states ${ }^{124}$ - Indonesia, Malaysia, the Philippines, Singapore and Thailand ${ }^{125}$ - to an organization

116 ibid., 308.

117 ibid., 304-11.

118 ibid., 309.

119 ibid., 310.

120 See Alizedney M. Ditucalan, Chapter 13 of this volume.

121 See UNCTAD (n. 110 above).

122 Steven Van Uytsel and Somsack Hongvichit, Chapter 14 of this volume.

123 Ploykaew Porananond, Competition Law in the ASEAN Countries: Regional Law and National Systems (Wolters Kluwer 2018) 2.

124 ibid., 3.

125 ASEAN, 'Establishment', available at: https://asean.org/asean/about-asean/overview/ (accessed 5 October 2019), stating that 'The Association of Southeast Asian Nations, or ASEAN, was established on 
coordinating economic development in a region that has expanded to include a total of ten member states: ${ }^{126}$ besides the original member states, also Brunei Darussalam, Viet Nam, Lao PDR and Cambodia. ${ }^{127}$

The reinvention of the organization as a tool for economic integration was a response to the rapid growth of China and India. ${ }^{128}$ This originally translated into the conclusion of the ASEAN Preferential Trading Agreements, the ASEAN Industrial Projects, the ASEAN Industrial Complementation and the ASEAN Industrial Joint Venture Scheme. ${ }^{129}$ Without clear results from economic coordination, the ASEAN leaders opted for the creation of a free trade area, the ASEAN Free Trade Area (AFTA), which was later supplemented by the ASEAN Framework Agreement on Services and the ASEAN Investment Area. ${ }^{130}$ However, the AFTA fell short of its goal to stimulate intraregional trade, ${ }^{131}$ designed more to attract foreign direct investment. ${ }^{132}$ A new impetus to achieve more interregional trade came in 1997, when ASEAN Vision 2020 was presented at the Second Informal ASEAN Summit in Malaysia. ${ }^{133}$ ASEAN Vision 2020 aimed at closer economic ties between the ASEAN Member States, without discarding the need for a peaceful and stable region. On the basis of this document, the ASEAN leaders then decided to proceed along three pillars: the ASEAN Political-Security Community (APSC), the ASEAN Socio-Cultural Community (ASCC) and the ASEAN Economic Community (AEC). ${ }^{134}$

The AEC was regarded as the most feasible of all three pillars. Inspired by its European counterpart, the European Union, the AEC aimed at 'regional economic integration with free movements of goods, services, investment, skilled labor, and the freer flow of capital'. ${ }^{135}$ One of the aims of the AEC, the ASEAN Economic Community Blueprint (AEC Blueprint) tells us, is the creation of a highly competitive economic region. ${ }^{136}$ To support such a highly competitive economic region, the AEC Blueprint laid down that it would be beneficial for the ASEAN Member States to have, among others, ${ }^{137}$ a national competition law. The emphasis is on national competition law, without the need for the enforcement

8 August 1967 in Bangkok, Thailand, with the signing of the ASEAN Declaration (Bangkok Declaration) by the Founding Fathers of ASEAN, namely Indonesia, Malaysia, Philippines, Singapore and Thailand.'

126 Porananond (n. 123 above) at 4-10.

127 ibid., detailing that 'Brunei Darussalam then joined on 7 January 1984, Viet Nam on 28 July 1995, Lao PDR and Myanmar on 23 July 1997, and Cambodia on 30 April 1999, making up what is today the ten Member States of ASEAN.'

128 Jacques Pelkmans, The ASEAN Economic Community: A Conceptual Approach (Cambridge University Press 2016) 12, 63 and 191; Siow Yue Chia and Michael G. Plummer, ASEAN Economic Cooperation and Integration: Progress, Challenges and Future Directions (Cambridge University Press 2015) 74.

129 Porananond (n. 123 above) at 5; Chia and Plummer (n. 128 above) at 39-48.

130 Chia and Plummer (n. 128 above) at 48-67.

131 ibid., 68-9.

132 ibid.

133 Porananond (n. 123 above) at 6.

134 ibid., 7.

135 ibid.

136 See ASEAN, ASEAN Economic Community Blueprint 5-6 (ASEAN Secretariat 2008), available at https://asean.org/wp-content/uploads/archive/5187-10.pdf (accessed 5 October 2019).

137 Other elements required were consumer protection measures, intellectual property laws, infrastructure development, taxation reform and e-commerce. See ibid., 19-23. 
agencies to assist in the creation of a single economic market. ${ }^{138}$ This is probably in line with the 'ASEAN way', in which the choice for a national approach allows for 'maximum flexibility to take into account their respective socio-economic and political landscapes in the process of introducing competition law frameworks to their respective jurisdictions'. ${ }^{139}$

By the time of the call for national competition laws in 2008, only four ASEAN Member States had a competition law: Indonesia (1999), Thailand (1999), Singapore (2004) and Vietnam (2004). ${ }^{140}$ To facilitate the other member states in their process of enacting a competition law, the ASEAN Expert Group on Competition (Expert Group), established in 2007 to discuss and coordinate competition policies among the ASEAN Member States, released the ASEAN Regional Guidelines on Competition Policy (Regional Guidelines) in 2010. ${ }^{141}$ The Expert Group worked on these guidelines for a period of two years and drew inspiration from the experiences of some of the member states and other mature competition law regimes. ${ }^{142}$ The Regional Guidelines are a guidebook for writing a competition law. They address and detail the possible goals of competition law, the scope of competition law (horizontal and vertical agreements, abuse of dominant position, mergers and exemptions) and the enforcement structure (including the regulatory body, the institutional structure and relations with sectoral regulators and enforcement powers). ${ }^{143}$

Two years later, in 2012, the Expert Group, though in a different composition, complemented the Regional Guidelines with the Guidelines on Developing Core Competencies in Competition Policy and Law for ASEAN (Competencies Guidelines). ${ }^{144}$ The Competencies Guidelines are less focused on substantial competition law. After repeating the benefits of competition with reference to regional examples and emphasizing that, with the help of experts, the appropriate substantive provisions have to be chosen, the Competencies Guidelines elaborate on the conceptualization of the enforcement institution, the enforcement policy and advocacy. ${ }^{145}$

The risk with formulating guidelines is the creation of a perception that a universal competition law design is feasible. To overcome this risk, and so follow the findings of the literature on competition law and developing countries, the conceptualization of the

138 Note that the request to adopt a competition law is not included in the Blueprint's section on 'Single Market and Production Base'. Therefore, Burton Ong mentions that the main purpose of the competition law is probably to help attract foreign investment. See Burton Ong, 'Competition Law and Policy in the ASEAN Region: Origins, Objectives and Opportunities' in Burton Ong (ed.) The Regionalisation of Competition Law and Policy within the ASEAN Economic Community (Cambridge University Press 2018) 6 .

139 Ong (n. 138 above) at 6.

140 Porananond (n. 123 above) at 8.

141 Ong (n. 138 above) at 8-9. For the guidelines, see ASEAN, ASEAN Regional Guidelines on Competition Policy (The ASEAN Secretariat 2010), available at: www.asean.org/wp-content/uploads/ images/2012/publications/ASEAN\%20Regional\%20Guidelines\%20on\%20Competition\%20Policy.pdf (accessed 5 October 2019).

142 Ong (n. 138 above) at 9; Porananond (n. 123 above) at 67.

143 ASEAN (n. 136 above) at 3-44.

144 Ong (n. 138 above) at 22; Porananond (n. 123 above) at 67; for the guidelines, see ASEAN, Guidelines on Developing Core Competencies in Competition Policy and Law for ASEAN (The ASEAN Secretariat 2012), available at: https://asean-competition.org/file/post_image/Regional\%20Core \%20Competencies.pdf (accessed 5 October 2019).

145 ASEAN (n. 144 above) at 6-72. 
guidelines is crucial. The guidelines should point to the socioeconomic differences and connect these with appropriate suggestions for the formulation of a competition law. The Expert Group, in both its settings, were aware of this issue. ${ }^{146}$ The Regional Guidelines, for example, recognize that the ASEAN Member States are in different stages of competition policy development. ${ }^{147}$ Similarly, the Competencies Guidelines emphasize the difference in economic, social and political development among the different ASEAN Member States. ${ }^{148}$ Further, the Competencies Guidelines mention two other characteristics of some of the ASEAN Member States which may require a specific competition law: the importance of the informal economy and the size of the economy. ${ }^{149}$

Despite the expression of awareness of that an existing competition law may not be suitable for the ASEAN Member States, the Regional Guidelines, especially when elaborating the scope of competition law, tend towards the competition rules of the Treaty of the European Union, its implementing Regulations and Notices and its case law. ${ }^{150}$ This is most obvious in the choice of terminology. To describe the scope of competition law, the Regional Guidelines use words like 'undertaking', 'prevent, distort, or restrict', 'object or effect' and 'abuse of a dominant position'. It has been further documented that the European influence extends to the interpretation of many of these words. The emphasis for defining 'undertaking' is on any person engaging in an economic activity. Agreements are widely understood to include anything that may express the consensus among undertakings, no matter the form it takes. Abuse is said to be inspired by a decision of the Court of Justice of the European Union that holds that exploitative and exclusionary behaviour should be addressed. The former is considered negative for the consumers, while the latter could harm the market structure. The Expert Group looked at the merger regulation of the European Union to summarize into one paragraph the definition of a concentration as it is stipulated in several subsections of Article 3 of the European Merger Regulation.

The perception that competition law could be drawn from one model is weakened by the use of words like 'may', 'could', 'should' and 'can', fortifying the nonbinding character of the Regional Guidelines. The nonbinding character indicates that the ASEAN Member States are free to either neglect the suggestion or choose an alternative of the Regional Guidelines. However, the Regional Guidelines often fail to indicate why a suggestion should be neglected or what the possible alternatives are. In turn, this contributes to the complexity of these documents for the creation of a competition law.

The European influence is less directly detectable in the institutional framework of the Regional and Competence Guidelines. The Regional Guidelines are short on the institutional framework. ${ }^{151}$ The Competence Guidelines are more elaborative. ${ }^{152}$ This Guideline recognizes that there are different institutional enforcement models. These models - the adversarial judicial model, the adversarial agency model, and the inquisitorial model -

146 Porananond (n. 123 above) at 68.

147 ASEAN (n. 136 above) at 2.

148 ASEAN (n. 144 above) at 13-14 and 28-9.

149 ibid. (but it was held not to be that important for the ASEAN context at the end).

150 For a detailed discussion, see Ong (n. 138 above) at 10-21 and Porananond (n. 123 above) at 82-98.

151 ASEAN (n. 136 above) at 15-20.

152 ASEAN (n. 144 above) at 29-50. 
are all mentioned in the text of the Competence Guidelines. ${ }^{153}$ When the Competence Guidelines discuss the different models - and this is a big difference from the other recommendations in the Regional and Competence Guidelines - they also give explicit advice on which model is to be preferred. It is at this point that they push for the European model. A US-like adversarial judicial enforcement model, in which the investigation is done by an administrative agency and the adjudicating powers rest with the courts, is discarded because it requires a well-functioning judicial system. A Canada-like adversarial agency model, which requires the establishment of a specialized administrative investigation agency bringing complaints before a specialized adjudicative agency, is not suggested because experience has learned that few cases are brought to the adjudicative agency and everything tends to be settled before it reaches the adjudicative agency. The preferred system is the European-like inquisitorial model or integrated agency model, in which the investigative and adjudicative functions are all operated by a specialized administrative agency, for three reasons. First, the limited resources should not be spread over different organs. Second, this model is most spread among the experienced competition regimes. Third, a specialized agency is better equipped to reach a coherent enforcement policy suitable for the respective countries' situation.

ASEAN leaves its member states with a conundrum. On the one hand, ASEAN advocates for locally grown competition laws. In this sense, ASEAN parallels the discussion on competition law for developing countries. On the other hand, ASEAN suggests convergence with the European competition law and enforcement regime. Indirectly, it implies that this regime has won the battle in the process of convergence as advocated for by the ICN.

\section{CONCLUSION}

Over a period of five decades, the landscape for advice on adopting a competition law has drastically changed. Early adopters of competition law had only one model: the competition laws of the United States. However, the early adopters figured out that the initial model was not fully suitable for their country. Changes were being made. New competition law models were born. These new models were not necessarily advocating the same competition law principles and policies as the United States. Hence, when countries started to make a shift towards adopting a competition law, they were confronted with models that could potentially have contradictory claims.

To overcome the contradictory claims, scholarship developed to convince the potential adopters of a competition law to choose an economic approach towards that law. Underlying this kind of scholarship is the idea that an economic approach is superior to any other approach. This superiority will eventually drive all competition laws to converge on the economic standard. Deviations were considered as inappropriate applications of competition law. Hence, competition law models not following the economic standard should, if one applies this scholarship, not be followed. This could fortify the contradictory claims mentioned earlier.

\footnotetext{
153 ibid., 31.
} 
The strong stance against adopting an economic approach taken by some of the competition law regimes triggered a different approach: differentiation. Competition laws across the globe could and should be different if necessitated by the circumstances of the country adopting the competition law. This message was spread in two different ways. The enforcement agencies grouped themselves in the ICN. The stance of the ICN was that diversity in competition law should be accepted, but thorough study of these differences should be undertaken in order to establish what eventually proves the best practice. Even though differentiation is advocated for, the contradiction is that the best practice is again a reflection of the more advanced competition law regimes. Scholars, guiding countries in the competition law adoption process, also developed a stance in favour of differentiation. Each country should adopt a competition law adjusted to its needs and capabilities.

ASEAN has partly undermined the differentiation scholarship. Despite embracing the idea of differentiation in various of its official documents, ASEAN has adopted guidelines for writing a competition law based on the substantive law provisions of the European competition law provisions. 